\title{
Una reconciliación mística y mitológica: la imagen poética en "Retorno de Electra", de Enriqueta Ochoa
}

\author{
A mystical and mythological reconciliation: the poetic image in "Retorno de Electra", by \\ Enriqueta Ochoa
}

\section{Omar Armando Paredes Crespo}

Universidad Autónoma Metropolitana - Azcapotzalco (MÉXICO)

CE: omararmandoparedescrespo@gmail.com / ID ORCID: 0000-0003-4451-1200

DOI: $\underline{10.32870 / \text { sincronia.axxiv.n77.15a20 }}$

Esta obra está bajo una Licencia Creative Commons Atribución-NoComercial 4.0 Internacional $\mathrm{BY} \cdot \mathrm{NC}$

Recibido: $27 / 08 / 2019$

Revisado: $08 / 10 / 2019$

Aprobado: $24 / 11 / 2019$

\section{RESUMEN}

Caracterizada por su desgarramiento emocional, la poesía de Enriqueta Ochoa se erige sobre lo profundo de la existencia, sobre todo aquello que se revela terrible en el hombre. En "Retorno de Electra", la poeta coahuilense enlaza el mito y el misterio de la ausencia, los cuales parecen avanzar en direcciones contrarias pero que, al ser descubiertas en cada uno de los versos, dan origen a una serie de imágenes. Este artículo muestra, a través de la poética de Octavio Paz sobre la función de la imagen en la poesía, cómo es que Ochoa reconcilia el sentido místico de la ausencia del padre con la recurrencia del patriarca mítico en las tradiciones griega y cristiana para así construir una de las obras fundamentales de la tradición poética mexicana del siglo XX.

Palabras clave: Enriqueta Ochoa. Retorno de Electra. Poesía mexicana. Imagen poética.

\section{ABSTRACT}


Characterized by its emotional tearing, the poetry of Enriqueta Ochoa stands on the depths of existence, especially what is revealed terrible in man. In "Retorno de Electra", the coahuilense poet links the myth and the mystery of absence, which seem to move in opposite directions but which, when discovered in each of the verses, give origin to a series of poetic images. This article shows, using the poetics of Octavio Paz regarding the function of the image in poetry, how Ochoa reconciles the mystical sense of the father's absence with the recurrence of the mystical patriarch in the Greek and Christian traditions to, thus, configure one of the fundamental works of the mexican poetic tradition of the twentieth century.

Keywords: Enriqueta Ochoa. Retorno de Electra. Mexican poetry. Poetic image.

Toda la vida, incluyendo la longevidad, se la debo a la poesía. La poesía me mantiene en contacto con lo sagrado y lo profundo. Es una bendición haber vivido [tantos años] con la poesía, ¿qué mejor compañera? (Entrevista a Enriqueta Ochoa, 2009)

Hacia los años setenta, Enriqueta Ochoa (Torreón, Coahuila, 1928 - Ciudad de México, 2008) comenzó una tarea difícil para todo poeta que como ella ha dado una obra brillante: ser crítico y juez de su propia poesía. De este ejercicio autorreflexivo surgió Retorno de Electra (1978), libro que recoge los poemas mejor logrados y más importantes de sus poemarios anteriores, tales como Las urgencias de un Dios (escrito entre 1947 y 1950), Los himnos del ciego (1969), Cartas para el hermano (1973), entre algunos otros poemas que fueron publicados en diarios, revistas y antologías.

Poco difundida - si se compara con la obra poética de sus coetáneos Jaime Sabines y Rosario Castellanos, pues ella misma rechazó la autopromoción-, la poesía de Enriqueta Ochoa está atravesada por una experiencia mística, por la proximidad de la muerte como parte y forma de la vida 
y un desgarramiento emocional e íntimo. Basta leer "Retorno de Electra" ${ }^{1}$, elegía con la que la poeta significa la muerte de su padre, para dar cuenta de ello.

Cuando "Retorno de Electra" ${ }^{2}$ figuró por primera vez en un libro fue en este volumen homónimo, en el que apareció junto a "Estela en la luz", poema dedicado a la memoria de Estela Ochoa, hermana de la poeta, quien se suicidó tras la muerte de su madre. Ambos integran el brevísimo apartado final de este poemario; los dos concentran en cada una de sus imágenes esta ausencia que, dolorosa, se transfigura en una poderosa experiencia confesional.

En "Retorno de Electra" queda contenida una fuerza extraña - casi indescriptible - en la que el yo lírico entabla un diálogo no solo con el padre, sino con la ausencia y el vacío de este. Un poema plenamente vivencial, un conjunto de figuras que evidencia la erudición y el talento de Enriqueta Ochoa para reconciliar significados que parecían avanzar uno contra el otro. Demostró que la muerte también es origen. Partiendo de la poética de Octavio Paz respecto a la función de la imagen en la poesía, propuesta en El arco y la lira (1956), este estudio analiza la reconciliación de dos conceptos abstraídos en figuras poéticas en este poema: la ausencia del padre como experiencia mística y la recurrencia del patriarca mítico de las tradiciones griega y cristiana.

José Francisco Conde Ortega (2002, p. 340) escribe que en este poema Ochoa establece una relación con dos tradiciones tutelares: la primera, la fundación de un mito que ha dado sentido a Occidente a través de la figura de Electra; la segunda, significar la realidad atroz que deja la ausencia del padre mediante un motivo literario. Conde explica que el poema puede leerse como una tragedia griega gracias a que se transforma en una experiencia universal, "una necesidad de la especie para ese intento desesperado de asediar el mundo de lo inefable".

\footnotetext{
${ }^{1}$ Samuel Gordon escribe que "El retorno de Electra" es una de las más importantes elegías de la poesía mexicana. Dedicado a recordar la muerte de su padre - señala Gordon-, se inserta en la larga cadena cuyo primer eslabón en castellano se halla en Manrique y sus "Coplas" hacia fines de 1476 y cuyo paralelo más próximo en la poesía mexicana se debe a Jaime Sabines con Algo sobre la muerte del mayor Sabines (Gordon, 2008-2009).

${ }^{2}$ Algunas versiones señalan que este poema pudo haber aparecido por primera vez en la revista La palabra y el hombre, de la Universidad Veracruzana, en 1975. Sin embargo, cuando salió en el poemario Retorno de Electra, el año que Enriqueta Ochoa escribe al final de este es 1976.
} 
Compuesto por cinco cantos sin corte estrófico y escrito en verso polimétrico con predominancia del endecasílabo a modo de dar cierta musicalidad al poema, "Retorno de Electra" utiliza la figura del mito griego de Electra, esta mujer que vuelve después de un tiempo, junto a su hermano Orestes, para vengar el asesinato de su padre Agamenón. Sin embargo, aquí no ocurren venganzas ni matricidios, pues la figura de Electra es utilizada como una metáfora de la nostalgia que pesa sobre la muerte del padre.

En una entrevista (Del Moral, 2009), la poeta se refiere a cada uno de los apartados de este poema como cantos. Esto se debe a que con cada uno de ellos divide los momentos del poema. En el primero, por ejemplo, Electra representa esta separación del padre mitológico; en el segundo, el anhelo y la melancolía se vierten sobre el padre religioso al recuperar episodios del Nuevo Testamento. Es importante destacar que Ochoa conocía bien las estructuras clásicas de la poesía, pero su decisión de estructurar este poema de tal forma se debe, quizá, a que en él yace un ejercicio de liberación emocional con el que pretendía renunciar a la formalidad.

Con un tono personal el yo lírico, en el primer canto, dialoga directamente con la ausencia, da testimonio de lo que ha ocurrido durante la falta y rememora el pasado en los versos que refieren a la muerte del padre:

Con tu muerte se quebrantaron todos los cimientos;

no me atreví a buscar,

porque no habría

un roble con tu sombra y tu medida

que me cubriera de la llaga de sol en mi verano. (Ochoa, 1978, p. 150).

La voz no renuncia a su matiz vivencial — rasgo en la poesía de Enriqueta Ochoa - y evoca a la idea trágica de que, con la muerte del supremo, del rey, o del emperador, lo único que queda en el sitio que gobernó es caos y destrucción. 
Por otro lado, si se analizan los verbos de este poema se dará cuenta de que todos están vinculados a un sentimiento de desolación y ausencia (tal y como ocurre en la elegía); tan solo en el primer canto hay cuatro versos en los que aparecen cuatro verbos, tres de ellos son devastadores:

Y cuidar que no se me encogieran las palabras,

el corazón, los ojos

porque aún se me deshacen de agua

si te nombro. (Ochoa, 1978, p. 150).

Los dos primeros, encogieran y deshacen, son consecuencia del último: nombro. Con estos verbos Ochoa construye una imagen del recuerdo, mismo que al materializarse en palabra se transforma en silencio y llanto. Es importante señalar cómo la poeta empleó la metonimia para que la imagen se explicara a sí misma.

Octavio Paz escribe que las imágenes del poeta son auténticas y que constituyen una realidad objetiva, son obras. Con la autenticidad en estas imágenes el poeta se refiere a que han nacido de una visión y experiencia del mundo, por otro lado - explica-, crean realidades dueñas de una verdad, la de su propia existencia (2018, p. 107). En este sentido, en "Retorno de Electra" Enriqueta Ochoa representa por medio de la retórica un universo que, aunque es personal e interior, sitúa en una realidad cercana: la ausencia del Otro. Hace de la asimilación individual un acto de experiencia universal.

El primer canto no solo evoca, como se ha mencionado, a un padre mitológico, sino a la orfandad y al momento en que esta voz, para encontrar al padre, tiene que deshacerse a sí misma, suplantarlo, volverse hacia él:

Y no pude decir,

hasta que se hizo carne de mi carne el amor

lo que era hallar la propia sombra, entregándose.

Después quise ubicarte en mí, te pesé,

te ultrajé, te lloré, medí tus actos;

di vuelta atrás, 


\section{y volví a caminar lo desandado;}

por eso puedo hablarte ahora, así, porque entendí tu medida de gigante. (Ochoa, 1978, p. 150)

En estos versos, con los que Enriqueta cierra el primer canto, hace una búsqueda del padre a través de ella; mediante su experiencia quizá como madre. Es importante destacar el verso "y volví a caminar lo desandado", pues en el verso cinco escribe "Tuve que desandar lo caminado"; hace una inversión del participio entre uno y otro, lo que recobra sentido si se interpreta, este primer canto, como una búsqueda del recuerdo y el pasado en el vacío, ese ir y venir para rememorar la vida, ahora, como parte de la muerte.

A través de estas figuras la imagen reconcilia no solo estas dos últimas (vida y muerte), tampoco tristeza y resignación; vincula, también, incertidumbre y revelación: incertidumbre por el espacio de la ausencia y revelación ante la posibilidad de significar la ausencia del Otro a través de la vida misma, de la propia existencia.

En este primer canto, quizá el más poderoso del poema, Enriqueta Ochoa transforma la nostalgia en imágenes poéticas, pues cada uno de los versos encarna la melancolía de un luto que ha sido guardado por más de veinte años, pues su padre don Macedonio Ochoa murió en 1953. “Retorno de Electra" pudo haber sido escrito entre 1975 y 1976.

Ese trabajo fue interior, fue en el espíritu, fue llorar y sufrir mucho por la muerte de mi padre. De pronto este poema sale una tarde en que yo estoy esperando que salga mi hija de la escuela, se mueven unas cortinitas, así con el soplo de la tarde, y en ese instante algo me recuerda, algo muy grande, muy profundo me lo recuerda, de tal manera que me suelto escribiendo. Así nace todo el primer canto, en ese ratito, en diez minutos. Había tenido que esperar veinte años para que saliera ese pedacito. (Del Moral, 2009, párr. 14)

Cuando los versos de este canto se refieren de manera directa al padre, Enriqueta Ochoa utiliza las imágenes; por ejemplo, se refiere a él como patriarca, viejo de barba azul, ojos de plomo, roble, gigante. Por su naturaleza, aunado al tema poético, estos adjetivos confieren a esta figura un 
simbolismo mitológico que establece un sincretismo con Agamenón en el mito de Electra. Este canto es un acto de confesión a la memoria pues constantemente revela al padre qué ha sucedido desde su partida, qué le ha ocurrido a ella desde que quedó en la orfandad.

Ya me creció la voz, padre, patriarca,

viejo de barba azul y ojos de plomo;

ya te puedo contar lo que ha pasado

desde que tú te fuiste. (Ochoa, 1978, p. 150)

No es una casualidad, ni tampoco resulta extraño que ante la hipérbole el sentido poético recobre un tono infantil, tal y como sucede en estos versos, pues la experiencia se mueve de la niñez a la juventud. Enriqueta Ochoa se mira a sí misma como una niña y hace un recuento sobre la pesadez de la ausencia en los años. De esta manera, a través de su voz y de los versos, la esencia de su padre se transforma en existencia. Se vuelve posible en medida que el yo lírico nos coloca frente al vacío.

Respecto a esta cualidad poética, Octavio Paz (2018, p.109) explica que la función del poeta no es describir sino colocarnos justo frente a esa realidad. Enriqueta Ochoa, en este primer canto, logra por medio de este artificio colocarnos frente a esa ausencia, dentro de ese vacío que experimenta. Samuel Gordon (2008-2009) señala que Enriqueta Ochoa, después de escribir este poema, finalmente logra sepultar a su padre. En este sentido, la asimilación de un dolor callado se transforma en un grito poético en el que por fin, después de muchos años, la poeta logra hablar con su padre, así, de frente, "desnudando la piel de su conciencia” (Ochoa, 1978, p. 150).

\section{Una reconciliación mitológica}

En el segundo canto Enriqueta Ochoa significa la ausencia del padre religioso, y por eso utiliza referencias mitológicas del Nuevo Testamento. La elegía entonces se vuelve hacia la culpa. Hacia la distancia.

Este canto conserva la confesión, sin embargo, ya no se refiere directamente a la ausencia del padre, sino a sí misma. La mayoría de los versos aluden a un yo; para muestra, el verbo "ser" 
particulariza las acciones de la voz que se culpa, que se flagela. Que el verbo esté conjugado en presente expresa un sentimiento que no la ha abandonado. Quizá esto pueda tener relación con la culpa que la poeta sintió al recluirse en un convento en la Ciudad de México al mismo tiempo que su padre agonizaba en las dolencias de una enfermedad que finalmente lo llevó a la muerte. Enriqueta Ochoa siempre lamentó desconocer la gravedad del estado de su padre, por lo que nunca se perdonó no haberlo acompañado en sus últimos meses como ella hubiese querido. Este episodio podría estar contenido en los siguientes versos del segundo canto:

Soy el martillo cayendo sobre tus clavos;

el aire que no asistió al pulmón en agonía;

soy la que no compartió

el dolor anticipado que se encerró a devorarse; (Ochoa, 1978, p. 151)

Aquí se halla una referencia a la crucifixión de Cristo, específicamente en los clavos y la Vera Cruz, reliquias que en la tradición cristiana connotan dolor y agonía. La imagen aquí funciona en dos sentidos. Primero, vincula dos tradiciones: el mito griego y el mito cristiano, ambos están evocando la memoria; el segundo enaltece la figura del padre - que es ausencia - sobre una realidad más cercana e inmediata que no tiene que ver precisamente con la necesidad de Dios, sino con la culpa llevada como un estigma.

Se mencionó que la imagen en el segundo canto establece relaciones entre dos mitos, el griego y el cristiano. Sobre esto, Martha Lorena Botello Moreno escribe:

Esta combinación no solo nos habla de la conciencia de la autora por reflejar su cosmogonía sino de una intención estética perfectamente consciente de llevar a una misma realidad dos tradiciones radicalmente opuestas y hacer que se realimenten una a la otra; que una ilumine a la otra y viceversa. El resultado estético es, por un lado, la actualización del mito, pero por el otro, la identificación de dos mitologías en un contexto poético y el nacimiento de una tercera imagen en la mente del lector donde tienen lugar correlaciones simbólicas y semánticas. La creación de un panorama distinto en donde podemos reconocer a esa Electra ancestral e 
identificarnos con sus sentimientos, con sus reflexiones, con su dolor y con su nostalgia. (2015, p.49)

Las referencias de los apóstoles Pedro y Santiago, quienes envuelven esta recurrencia sagrada respecto a la insinuación de Cristo en el segundo canto, funcionan como reminiscencias de la memoria durante la agonía del padre. Es decir, recuperan un recuerdo doloroso y trascendente para Enriqueta Ochoa, lo mismo que la culpa:

Padre, soy Pedro y Santiago,

el sable que doblado de sueño

castró su espíritu en tu oración del huerto.

Yo soy el viscoso miedo de Pedro

que se escurrió en la sombra

a la hora de tus merecimientos. (Ochoa, 1978, p. 151)

Por su apego al pasaje bíblico, la poeta parece transportar su propio miedo a la figura de Pedro, en esta idea del testigo frente a la muerte del supremo. Jesús, Agamenón y Macedonio Ochoa conforman entonces una especie de sincretismo místico-mitológico.

La referencia de los apóstoles Pedro y Santiago pudiese tener relación con las lecturas que Enriqueta Ochoa dedicó a la Biblia, pasajes que utilizó para simbolizar la culpabilidad y el miedo. En el Libro Sagrado se lee:

36 Entonces llegó Jesús con ellos á la aldea que se llama Gethsemaní, y dice á sus discípulos. Sentaos aquí, hasta que vaya allí y ore.

37 Y tomando á Pedro, a y los dos hijos de Zebedeo, comenzó a entristecerse y á angustiarse en gran manera.

38 Entonces Jesús les dice: Mi alma está muy triste hasta la muerte; quedaos aquí, y velad conmigo.

39 Y yéndose un poco más adelante se postró sobre su rostro, orando, y diciendo: Padre mío, si es posible, pase de mí este vaso; empero no como yo quiero, sino como tú. 
40 Y vino á sus discípulos, y los halló durmiendo, y dijo á Pedro: ¿Así no habéis podido velar conmigo una hora?

41 Velad y horad, para que no entréis en tentación el espíritu á la verdad está presto, mas la carne enferma.

42 Otra vez fue, segunda vez, y oró diciendo Padre mío, si no puede este vaso pasar de mí sin que yo lo beba, hágase tu voluntad.

43 Y vino, y los halló otra vez durmiendo, porque los ojos de ellos estaban agravados.

44 Y dejándolos fuese de nuevo, y oró tercera vez, diciendo las mismas palabras.

45 Entonces vino á sus discípulos, y díceles: Dormid ya, y descansad he aquí ha llegado la hora, y el Hijo del hombre es entregado en manos de pecadores. (Mateo, 26:36-45).

En estos pasajes bíblicos se cuenta la captura del Cristo en el huerto de los olivos, lugar en el que oró una noche antes de ser llevado a juicio. Enriqueta Ochoa utiliza la figura del apóstol para encarnar su culpa, para simbolizar ese letargo que la inmovilizó ante la muerte de su padre, tal y como ocurre con el sueño de Pedro, Juan y Santiago según las Sagradas Escrituras.

Si se analizan los verbos de este segundo canto se habrá de constatar que todos conservan un tono elegiaco. En los versos tres, siete, catorce y diecisiete, los verbos son retuercer, castrar, encerrar y hundir, respectivamente. Éstos refieren un sufrimiento desmedido frente a una culpa anticipada.

Se ha mencionado anteriormente que una de las imágenes que representa este canto es el de la culpa como una marca de estigma durante los años. De este modo, hacia el final del segundo canto, el yo lírico se hace dos preguntas que no se refieren a la osamenta - aunque pudiera entenderse de esa manera - sino a la pesadez de la muerte y la ausencia en la memoria. El segundo canto concluye con los siguientes versos:

Soy este pozo de noche en que se hunde la conciencia.

Di, ¿qué se hace con un muerto, padre?

Di cómo lavo estas llagas,

si todo queda inscrito en el tiempo 
y todo tiempo es memoria. (Ochoa, 1978, p. 151)

\section{Naturaleza corpórea. Una reconciliación mística}

Enriqueta Ochoa contó que tras la muerte de su padre siguieron muchas otras, por lo que el tercer canto recupera estos episodios y coloca la ausencia del padre como un acontecimiento causal. Cuando Enriqueta Ochoa utiliza esta imagen del racimo de la uva, el presentimiento del vértigo de la altura, la caída y el descenso, está transportando las vivencias a frases poéticas que cobran sentido por medio de la memoria. Al morir su padre, inmediatamente la salud de su madre mermó hasta que murió. Ante esta pérdida, Estela, hermana de la poeta, cayó en una fuerte depresión que terminó en suicidio. Alfredo, el otro hermano, comenzó a tomar hasta que un día falleció.

Enriqueta Ochoa utiliza la naturaleza como una metáfora del desprendimiento de la vida. De esta manera el padre se vuelve entidad elemental, sustancia orgánica, origen. Al referirse al padre, el yo lírico utiliza apelativos como fuerza, pesantez y amor, los cuales - en los versos en que son utilizados - contrastan con reblandecer, esencia y espina, respectivamente. Son interesantes estos binomios porque en su relación semántica dentro del poema construyen imágenes poéticas contrarias que, al mismo tiempo, no pueden ser desprendidas una de la otra.

Colgábamos de ti

como del racimo la uva.

Cuando la muerte

reblandeció el cogollo de tu fuerza,

presentimos el vértigo de altura y la caída,

Uno a uno,

en relación directa a la pesantez de tu esencia,

descendimos.

Bajo anónimas pisadas me vi saltar la pulpa,

sorprendida.

Y no era orgía de vendimia,

ni enervación de culto; 
fue ser la sangre a la sed de todos los caminos;

dejar la piel desprendida

entre un enjambre de alambradas.

Ahora,

para afirmar la talla

con que tu amor me hizo,

sólo queda una espina:

la palabra. (Ochoa, 1978, p. 151)

Octavio Paz escribe que designamos como imagen toda forma verbal, frase o conjunto de frases que el poeta dice y que unidas son un poema:

Por su parte, la retórica se ha encargado de clasificar estas expresiones y llamarlas símbolos, alegorías, metáforas o como toda figura que tenga como función preservar la pluralidad de significados de la palabra sin quebrantar la unidad sintáctica de la frase o el conjunto de éstas (sic)" (2018, p. 98).

En las dos primeras relaciones (los dos primeros pares de palabras que resaltan), la imagen es una hipérbole donde ambas palabras no avanzan una contraria a la otra, sino que una tiene efecto sobre la otra, lo que da origen a un nuevo significado: en el primero, el padre - poderoso y gigante, como lo llama en el primer canto- solo puede sucumbir ante la muerte; en el segundo la magnitud del vacío es proporcional a la magnitud de la figura, una muerte que seduce y envuelve otras vidas; finalmente, la última relación explica el amor como la esencia de lo que un día fue raíz y tallo, de lo que solo queda la espina y un sufrimiento cautivo que encuentra libertad en la palabra. La espina y la palabra conservan su sentido sagrado y mitológico en este canto.

En el cuarto canto el yo lírico ya no habla más a la ausencia del padre, rompe con esta referencia y habla directamente a los hermanos. El sentido de culpa se vuelve reclamo a sí misma por no advertir el dolor de sus hermanos y recluirse en el propio. Esta parte es reveladora ya que se comienza a vislumbrar ese anhelo catártico con el que rompe hacia el final: 
Perdón, hermanos,

porque no alcanzo a verlos,

ahogada como estoy en mi hoyo

de pequeñas miserias.

¡Mentira que deseo morir!,

antes quisiera conocerlos

sin mi lente deforme,

quizá los amaría tanto,

o más de lo que estoy amando

a mi lastre de lágrimas

en este viaje de niebla. (Ochoa, 1978, p. 152)

En este canto la imagen se concentra en la mirada, en una mirada nublada por el ardor; por eso la poeta hace alusión a la imposibilidad de esta, en donde se anteponen las lágrimas, la espesura, la deformidad y la oscuridad. En los versos de este canto la emoción contenida es directa y renuncia a toda ambigüedad. Además, Enriqueta Ochoa no modifica la sintaxis de los versos (hipérbaton) para que la expresión conserve su único significado: la culpa.

En el quinto y último canto, el yo lírico se coloca frente a la figura del padre para trascender en la experiencia de la muerte. Recurrentemente está evocando a un renunciamiento de sí misma para dejar atrás el dolor, la melancolía y la memoria -esta última ha pesado como lápida en su vida-:

Padre,

no puedo amar a nadie,

a nada que no sea este fuego

de sucia conmiseración

en que se consume mi lengua.

Quiero otro aire,

otro paisaje que no sean los muros de mi cuerpo.

Emparedada, desconozco el resplandor del centro 
y la desnudez de la periferia.

Voy a abrir brecha hacia los caminos

y quizá quede atrás

la trampa de la vieja noria. (Ochoa, 1978, p. 152)

En "Retorno de Electra" son visibles estas imágenes que enuncian una naturaleza corpórea en diálogo con la religiosidad mítica. Explicarlas por medio de razonamientos no es necesario ya que ellas se sustentan a sí mismas. Enriqueta Ochoa encontró en este poema la medida exacta de la catarsis pues, al mismo tiempo que configura una revelación íntima y dolorosa, mantiene un significado revelador.

La mitología, el misticismo y la memoria configuran imágenes poéticas en este poema; revelan la emoción de la autora contenida por años a medida que se transforman en una realidad que hace posible la ausencia del padre. Sobre este, Enriqueta Ochoa contó:

Hay que trabajar y trabajar con el dolor hasta que salga. Así me pasó a mí, yo sufría mucho, me autodestruía mucho. Una mañana, despierto y creo ver a mi papá, así como si estuviera todo vestido de andrajos. Me dice: "Déjame descansar, porque se me va a ir mi luz. No puedo descansar mientras te vea llorar." Yo le juro en ese momento que nunca más volverá a suceder nada de eso, que lo voy a dejar descansar para siempre. Jamás volví a llorar, jamás lo volví a recordar ni nada. Se vino el poema enterito. (Del Moral, 2009, párr. 16)

\section{Conclusiones}

En "Retorno de Electra" la noción de imagen poética propuesta por Octavio Paz en su ensayo El arco y la lira (1956) revela una experiencia emocional y mística sobre la ausencia del padre al mismo tiempo que la autora recupera algunas reminiscencias de la mitología griega y cristiana, utilizando la figura de Electra y Cristo, respectivamente. En el poema la vivencia de la vida y la muerte parecen ir en sentidos contrarios, sin embargo, avanzan de forma paralela a medida que se encuentran con la memoria. Es decir, la imagen poética reconcilia una realidad expresa y cercana a Enriqueta Ochoa (la de la muerte de su padre) a otra que sólo es posible a través la manifestación poética misma. 
Las figuras de Macedonio Ochoa, Agamenón y Cristo se construyen bajo una misma imagen que dialoga de tres formas diferentes: la pérdida del padre físico, la muerte del jerarca y la ausencia de todo aquello que le confiere religiosidad y fe a la vida. No es casualidad el que la poeta haya decidido unir a sus recuerdos estos mitos para después transfigurarlos en imágenes que cobran sentido en cada uno de los cinco cantos que integran "Retorno de Electra".

Por último, aunque en este poema persiste un evidente sentimiento de dolor y culpa, es posible vislumbrar en él un ejercicio de rescate, un acto de liberación que vino a significar una bocanada de aire puro en la vida de quien ha estado cerca de la muerte. El dolor y la libertad reconciliados por medio de un acto confesional que solo pudo materializarse en las imágenes de la poesía.

\section{Referencias}

Botello, M. (2015). "No hay palabra que alcance": Aproximación a la concepción de lo sagrado en la obra poética de Enriqueta Ochoa. Análisis mitocrítico (Tesis de maestría). México, UNAM.

Conde, J. (2002). “Enriqueta Ochoa: bajo el oro pequeño de otro mito", Tema y variaciones, (18), 331-344.

Del Moral, A. (1 de febrero de 2009) "Bautizada por el viento", entrevista a Enriqueta Ochoa. La Jornada Semanal, (726). Recuperado de: https://www.jornada.com.mx/2009/02/01/sem-adriana.html Gordon, S. (2008-2009). La estrategia confesional en la poesía de Enriqueta Ochoa, Periódico de Poesía, (15). Recuperado de: http://www.archivopdp.unam.mx/index.php/790

Ochoa, E. (1978). Retorno de Electra. México, Editorial Diógenes.

Paz, O. (2018). El arco y la lira, 3era. Edición. México, FCE. 